\title{
ORGANIZATIONAL POWER AND THE MANAGEMENT OF A MEGA-EVENT: THE CASE OF SYDNEY 2000
}

\author{
STEPHEN FRAWLEY \\ Australian Centre for Olympic Studies, UTS Business School, \\ University of Technology Sydney, Lindfield, NSW, Australia
}

\begin{abstract}
The organization of a mega-event such as the Olympic Games is a complex task involving a multitude of individuals and stakeholder groups. In 2000, Australia's largest city, Sydney, staged the Summer Olympic Games. The agency given primary responsibility for these Games was the Sydney Organizing Committee for the Olympic Games (SOCOG). Two additional organizations also played a central role in the management of the event: the Australian Olympic Committee and the New South Wales Government. This article explores the role played by the host national Olympic committee as a key Olympic stakeholder in the organization of the Olympic Games. The research highlights that organization of a mega-project, such as the Olympic Games, is not only the result of recent developments but also of countless social and organizational figurations that developed over many years prior to the winning of a bid to stage the event.
\end{abstract}

Key words: Mega-events; Olympic Games; Organizational power; Stakeholder management

Introduction

There is still much to learn about the involvement of key stakeholders in the organization of the Olympic Games. It has been suggested more research is required that explores issues relating to stakeholder power and the allocation of resources and the influence this relationship has on the staging of an Olympic Games (Parent, 2005). The purpose of this article is to drill down and look more specifically at these relationships. To address this knowledge gap the article examines how a host national Olympic committee (NOC) leveraged its power and authority in the organization of an Olympic Games. The Sydney 2000 Olympic Games is the central case used in the study. The role of the Australian Olympic Committee (AOC) as a stakeholder within in the host organizing committee-known as the Sydney Organizing Committee for the Olympic Games (SOCOG) — and more specifically in the organization and management of the department responsible for sport at the Sydney Games is analyzed.

The article is structured as follows. First, how the Sydney 2000 Olympics Games were organized 
is described. Second, a review of the literature relevant to the study is presented together with a discussion of the key elements involved in managing sport at an Olympics. Third, the theoretical framework and methodology employed are outlined. Lastly, the findings and analysis that emerged from the research are presented.

\section{Organizing Sydney 2000}

The governance structure of SOCOG was different to any Olympic Games held either before or since Sydney 2000. Typically, an organizing committee for the Olympic Games (OCOG) is governed by a single board, the makeup of which is stipulated in the Olympic Charter. However, in 1996, as a result of a contractual resolution between two key Olympic stakeholders, the AOC (as the host NOC) and the New South Wales (NSW) Government (as the financial underwriter for the Games), two separate governance structures were established (Frawley \& Toohey, 2009).

This meant, in effect, two distinct groups managed the Sydney Games, one with control and authority for the sport department and the other with the usual OCOG responsibilities (Toohey, 2001). The entity created with authority to manage the sport department within SOCOG was called the SOCOG Sports Commission (SSC). The SSC consisted of six members. The AOC was given the power to appoint four SSC members while the NSW Government appointed the remaining two (Gordon, 2003). The President of the AOC was appointed the SSC Chairperson.

The sport department within an OCOG is typically responsible for a number of different planning and organizational activities. These can be broadly separated into sport-specific and sport-related actions (Frawley, 2013). Sport-specific organizational activities refer to tasks completed predominantly by the sport department (SOCOG, 2000). Sport-related organizational activities refer to tasks completed by non-sport department within an organizing committee that are critical to the sport department in delivering its program of work (e.g., transport, venue management, and villages). While the sport department is not usually directly in control of these departments it works with them to provide advice and data that help the Games' coordination and decision making (Frawley, 2010).
Sport-specific organizational activities at an Olympic Games can include the following areas: development of the sport competition schedule; planning and management of test events; development of sport policies and operating procedures (i.e., sport medical policies and procedures); the management of the sport entries process including the tracking of athlete qualification; development and management sport results systems and sport related technology; sport presentation (i.e., lighting, sound, and announcements at competition venues); scoping and development of training venues; procurement of sports equipment; development and creation of sport publications; doping control; sport medical; liaison with the international sport federation relations; national Olympic committee relations; and IOC relations (SOCOG, 2000).

Sport-related organizational activities at an Olympic Games often includes (but are not limited to) the following areas: transport (i.e., athlete and official transportation to and from the Olympic village to training and competition venues); venues (i.e., the planning and management of sport competition venues); catering (i.e., athlete and official meals at competition venues); villages (i.e., athlete and official accommodation); workforce planning (i.e., the management of the volunteer recruitment process); accreditation (i.e., the development and management of the accreditation process for athletes and officials); marketing (i.e., the consequences of event sponsorship on the procurement of sport equipment); security (i.e., development of policies and strategies for athlete and venue security); broadcasting (i.e., development of policies for athlete press conferences and mixed zone areas - the space where journalists can interview athletes immediately post event); ceremonies (i.e., the planning for athlete and official involvement in opening and closing ceremonies); legal (i.e., development and implementation of legal strategies to counter ambush marketing); and logistics (i.e., the storing and transportation of sports equipment pre and post Games) (SOCOG, 2000).

\section{Olympic Organization Studies}

Olympic and mega-event research over the past three decades has largely focused on impacts and legacies (Cashman, 2006; Preuss, 2000). A small number of studies, however, have explored the 
internal organization of such events. For example, research has been completed investigating: organizational culture (McDonald, 1991), strategic management (Lowendahl, 1995; Malfas, 2003), strategic planning (Bramwell, 1997; Lesjo, 2000), stakeholder management (Parent, 2005; Theodoraki, 2007), sport participation and development (Frawley \& Cush, 2011), risk management and contingency/ security planning (Dobson \& Sinnamon, 2001; Minis \& Tsamboulas, 2008; Stamatakis, Gargalianos, Afthinos, \& Nassis, 2003; Toohey \& Taylor, 2008), and knowledge management (Halbwirth \& Toohey, 2001).

A clear gap in the literature at present is our understanding of the work of key stakeholders in the organization and management of specific OCOG departments, such as the sport department, at megaevents such as Olympic Games. The relevant studies mentioned above, that are focused on project ownership, strategic planning, and stakeholder management, are discussed in order to provide an overview of how the Olympic organization studies literature has developed over the past two decades.

\section{Event Ownership}

From a project management perspective, research conducted by Lowendahl (1995) into the staging of the 1994 Lillehammer Winter Olympic Games established that the effectiveness of the Games management was clearly influenced by the IOC and host OCOG relationship. The extent and level of project embeddedness determined the closeness of the fit between the project team (the OCOG) and the parent organization (the IOC). From this perspective, the fit of the parent organization and the project agencies were examined through the goals and objectives established by those agencies and the interrelationship between them (Lowendahl, 1995). Although it is standard in most projects for the parent organization to establish the project goals and objectives, Lowendahl (1995) demonstrated that with the Olympics it is somewhat different.

Lowendahl (1995) argued that for many standard projects the parent organization determines the organizational structure employed, the resources devoted to each department, the control mechanisms and risk management strategies employed, and the evaluation procedures that are adopted. In this case it is not only the owners of the event (i.e., the IOC) that may have different goals and objectives, but also the key stakeholders that invest heavily in the event. Governments, for instance, may have as their primary aim the creation of economic growth through tourism and destination marketing strategies or through demandside activity such as bring forward major infrastructure projects (Preuss, 2000). The host OCOG and its employees are often motivated to be part of an exciting project and for the Games they manage to be considered the "best ever" (Lowendahl, 1995). The IOC as the parent organization wants to grow the Olympic brand so it can strengthen sponsorship and broadcasting revenues and ensure its sustainability (Payne, 2006). Lowendahl (1995) argued that "the fact that there were three owners with very different objectives as well as numerous other stakeholders, made it impossible for any one owner to dictate their own objectives, routines, evaluation criteria exclusively” (p. 353). While Lowendahl examined the complexity of project ownership when managing an Olympics, other studies have examined the planning features that influence the management of similar mega-events.

\section{Event Planning}

Bramwell (1997) and Theodoraki (2007) have investigated the importance of strategic planning in the management of international sport events. Bramwell's (1997) research found that "too limited use of formal strategic planning may hinder [event] decision making” (p. 173) and that research and evaluation are required prior to and after event staging. Bramwell (1997) also argued that mega-event planning should be a participatory process, one that involves stakeholders in order to build the political legitimacy of the host organizing committee. Furthermore, it is important for organizing committees to consider the longer term perspective beyond the event itself (Bramwell, 1997).

Theodoraki (2007) showed how event planning and organizational parameters influence the formation of an OCOG. Drawing on the work of Mintzberg (1979), she highlights how OCOGs shift their job specialization from a department or functional area structure to a venue-focused structure. For example, in the early stages of an OCOG senior management create departments such as "finance, 
marketing, IOC, and Government relations. As these areas become more established and new staff are appointed, specialization increases horizontally to reflect the various levels of responsibility" (Theodoraki, 2007, p. 166). The increasing specialization of an OCOG immediately before the Games results in many staff shifting from department positions at headquarters to new positions at Olympic venues. This change demonstrates the shift from an organizational planning phase to an operational venue-based phase (Theodoraki, 2007). In some OCOGs this process is referred to as "venueization” (Frawley, 2010).

Although the work of Bramwell (1997) and Theodoraki (2007) focused on intended strategic decision making, the work of Lesjo (2000) explored the impact that unintended consequences have on Olympic organization. Lesjo (2000) utilized Eliasian process sociology as a framework to help examine how ideas and plans established by an Olympic bid committee "change radically" (p. 292) due to unplanned circumstances. Lesjo explored why the 1994 Lillehammer Winter Olympic Games became known for its environmental focus. He argued that the image of these Olympics as the "Green Games" (p. 293), while an important representation was not actually part of the original bid. However, an "unanticipated conjecture of symbolic politics and realpolitik produced Lillehammer's eventual image as an environmentally friendly city. A key aspect of constructing this 'green' profile was the cooptation of the environment movement” (Lesjo, 2000, p. 293) into Olympic planning.

Lesjo's (2000) research showed the impact unplanned and unintended consequences had on the organization of the Lillehammer Games. As Olympic event planning can take place over more than a decade (from bid to staging) new information becomes available and organizational standards and processes can and do change. Drawing on Hill (1992, 1996), Lesjo (2000) stated that the vast size and scale of the Olympic Games entwines "the bidders and hosts in unanticipated and complex figurations that they seldom understand” (p. 292). The research also illustrated the importance of understanding how the fluid and dynamic nature of stakeholder power relations influences event organization.

Utilizing the ideas of Elias (1994), Lesjo (2000) argued that the more democratic the mega-event organization is the more complex and difficult it becomes to anticipate organizational outcomes. Olympic organization at the Lillehammer Games was therefore "complicated by unplanned and unintended consequences, as well as the strategic actions of powerful players who change their original plans or have to negotiate compromises with subaltern groups" (Lesjo, 2000, p. 292). Lesjo further argued that other elements such as the weather cannot be entirely anticipated or even controlled by the best prepared Olympic planners. For instance, nice weather at an Olympics not only enhances the spectator and athlete experience, it also allows the media to broadcast images of the host city that are highly favorable and attractive.

\section{Event Stakeholder Management}

Over recent years strong research examining the roles of stakeholders in the organization of megasport events has been conducted by Parent (2005, 2008), Parent and Deephouse (2007), and Parent and Seguin (2007). This research has mainly centered on how event stakeholders shape and are shaped by event organizing committees. Parent (2008) and Parent and Deephouse (2007), for instance, conducted a study on the 1999 Pan American Games and the 2001 Jeux de la Francophonie. Through interviews with event managers Parent and her colleagues found that the theories regarding event structure and evolution as proposed by Getz (1993) and Hall (1992) did not accurately reflect the events they investigated. Instead, organizing modes were more often influenced by emerging issues and strategies rather than through formal organizational structures.

Another study explored stakeholder involvement in the organization of the 2005 World Swimming Championships (Parent \& Seguin, 2007). This research utilized stakeholder theory in order to understand the management difficulties that were faced by the organizing committee. Parent and Seguin (2007) found that "a lack of formal financial commitments, power congruence between partners and the persuasive politics, communication, proper human resource management procedures, and proper due diligence emerged as the critical combination of factors" (p. 187), resulting in a large organizational failure.

When examining the organization of the Sydney 2000 Olympic Games, Malfas (2003) similarly 
established that the event stakeholders influenced the workings of the host OCOG and therefore the event. The study highlighted the critical events that created organizational change for the host OCOG. These included: the observation of the 1996 Atlanta Olympic Games by senior management; the appointment of the NSW Minister for the Olympics and Paralympic Games, Michael Knight, to the position of SOCOG President; and the shift of SOCOG's organization control to the Main Operations Centre in May 2000 (Malfas, 2003). Malfas found that although the IOC, as the parent organization, had final responsibility for the Olympic project, it delegated a large amount of work to the host OCOG. This delegation can create a weak organizational model because the host OCOG itself is often highly dependent on government and other commercial institutions in order to deliver the Olympic Games. As a consequence of this limited involvement by the IOC, the loose organizational model provides opportunities for stronger stakeholders to strategically leverage and maximize their interests.

\section{Framework: Interdependent Processes and Olympic Organization}

The changing relationship over time between central Olympic stakeholders (such as the AOC and the NSW Government) provides a useful case study in understanding the evolving nature of organizational power. Critical management theorists such as Clegg, Courpasson, and Phillips (2006) argue that broader perspectives on the role of power in organizations is required in contrast to the common perspective in management theory, which views power as restrictive and as a negative force. The management literature, for instance, has often viewed power in terms of conflict situations and the consequences of its illegitimate exercise (Clegg \& Hardy, 1996). In attempting to understand organizational development and the influence of power and human agency a processual approach has substantive utility (Van Iterson, Mastenbroek, Newton, \& Smith, 2002). A processual perspective places an emphasis on analyzing shifting power relations between individuals as situated in an interdependent network that changes and develops over time (Dopson, 2005; Newton, 2001). The temporal characteristic of processual analysis provides the foundation for the choice of this theoretical framework in helping to understand how the sport department was organized at the Sydney 2000 Olympic Games.

The processual analysis employed in the study was guided by a number of principles. First, importance is placed on the interdisciplinary research links between disciplines such as sociology and history. As outlined by Elias (1994), any analysis of social experience or organization without history is barren and indistinct. Second, the concept of interdependent networks (Elias referred to them as figurations) are viewed as structures of mutually oriented and dependent people who develop and change over time (Newton \& Smith, 2002). Interdependent networks are therefore viewed as never being fixed but rather fluid and dynamic entities that change continually over time (Van Krieken, 1998). Third, developments in organizations are not only the result of planned action and agency but also due to unforeseen and unintended consequences of human action. As stated by Elias (cited in Newton, 1999) "underlying all intended interactions of human beings is their unintended interdependence” (p. 417). The fourth feature of a processual approach is the centrality of power in shaping and influencing human and organizational relations. Power in this instance is not viewed as a substance that can be possessed by any individual or group "but rather a characteristic of all human relationships” (Murphy, Sheard, \& Waddington, 2002, p. 93).

This particular perspective of power connects closely with the arguments presented by Foucault (1977). However, although power is relational it is also often asymmetrical with the balance of power between individuals and groups (organizations) in society rarely fixed or permanent (Arnason, 1987). Within every network some individuals and/ or groups will have more central roles with greater authority and at any one point in time and will be relied upon more heavily (Dopson, 2005). As organizations develop over time we can therefore see that power relations "reflect a complex interweaving of interdependencies amongst people, a 'networked agency'” (Newton, 1999, p. 420). This concept of power also closely aligns with the management research of Weick (1969), who has argued that when analyzing organizations "interdependence is the crucial element, interacts rather than acts are the crucial observables that must be specified” (p. 330). 
To gain an adequate understanding of mega-event planning and organizing it is therefore necessary to examine the context of power and the values supporting it (Flyvbjerg, 1998). As outlined by Flyvbjerg (2004) "rationality without power spells irrelevance" (p. 292). The contextual emphasis therefore is not only the exploration of power relations but also on their supporting values (Flyvbjerg, 2001). In line with this theoretical approach the study investigated the outcomes of the AOC's power relations with key Olympic stakeholders in the organization of sport at the Sydney 2000 Olympic Games.

\section{Methodology}

As outlined earlier, the purpose of this research was to understand the impact of a host NOC in the organization of an Olympic Games. The research also attempted to develop an understanding of the role and practices of a host NOC as a key Olympic stakeholder. To achieve this aim Sydney 2000 Olympic Games were chosen as the central case study. The key research question was therefore framed in the following way: How did the involvement of a host national Olympic committee influence the management of an Olympic Games?

To address this question a qualitative study was conducted that employed in-depth semistructured interviews. This approached allowed the researcher to draw on his experience and knowledge as a former Sydney 2000 employee and to collect deep and rich interview responses (Flyvbjerg, 2006). Great care was taken in this study to protect the identity of the respondents. Respondent confidentiality was treated as paramount at all times. In order to achieve this all interview transcripts were coded and stored separately. In total 35 interviews were conducted with former Olympic officials and senior SOCOG managers who were involved in the management and organization of the Sydney Games. Of these 35 respondents, 25 were interviewed in 2002 and 2003, while the remaining 10 were interviewed in 2009. This second data collection was completed to obtain additional data and because access was obtained to very senior Olympic officials that was not available in the earlier years of the data collection.

The subject selection was based on the principle of theoretical sampling that involved the direct selection of individuals within a defined population (Veal, 2006). The value of this approach is that it allows the targeting of key representatives who are able to provide a detailed knowledge of a specific organization or situation (Gratton \& Jones, 2004). After reviewing the initial data set, the researcher decided it would be worthwhile to increase the overall depth of the data collected for the study by completing the second round of interviews. Another advantage to emerge from the second round of interviews was that a number of the respondents had either worked directly for another OCOG post-Sydney 2000 or had consulted to one or a number of OCOGs and/or cities staging post-2000 Olympic Games. This additional experience provided these respondents with further knowledge that, in turn, informed the study. The majority of the interviews were conducted in person while some interviews were conducted by telephone. The average length of the interviews was 1 hour.

The analysis of the data was completed in three stages. This included data reduction, data coding, and data verification (Miles \& Huberman, 1994). Through reading and rereading of the interview transcripts data that was irrelevant to the study was excluded. As the interview transcripts were read and reread, key themes emerged. The software package Nvivo 7 was then employed to assist the management of the raw data through placement of relevant text into matching codes. As a result of this process, which included ongoing discussions with the members of research team, thematic categories were determined. Drawing on Gratton and Jones (2004), the data analysis was considered valid when the coding closely reflected what was being researched. Each code was distinct with minimal overlap, allowing for the data to fit accurately into each code (Veal, 2006). In addition, the researchers looked for statements that confirmed as well as refuted the research aims in order to build a rigorous data set (Bryman, 2004).

\section{Findings}

\section{Legitimate Authority}

As mentioned earlier, the SSC was formed as a result of contract renegotiations between the AOC and the NSW Government. The AOC's power in relation 
to the staging of the Sydney Olympics was constituted in legislation passed by the NSW Parliament. As such, it had legitimate authority within SOCOG to organize and manage the sport department. According to one respondent, the legitimate authority of the SSC meant it could make important decisions in a judicious and timely manner, reducing the "pathway you needed to go through to get things done, decisions made" (respondent 12). In addition, the capacity of the SSC to make fast and well-considered decisions was often juxtaposed by respondents with what "might have been" if these same decisions were left to the SOCOG Board. "If there had not been a SSC, it just would have taken so long to get decisions out of the Board" (respondent 9).

As a consequence of its authority the SSC was in a position to make sport-related decisions even though the SOCOG Board may have expressed a preference for a different position or policy. As outlined by respondent 33, the formation of the SSC was "essentially about the AOC retaining control of the key element of the Games. The AOC had a significant role in the functioning of the SSC, by establishing sports policy that was consistent with the AOC's focus on the athletes and Olympic principles.” From a similar perspective, respondent 9 commented that if critical sport-specific decisions were left to the SOCOG Board, they "could have taken months" because of the large number of financial and political matters the Board needed to manage.

\section{Decision-Making Capacity}

Such a decision-making capability was a central strength of the SSC (respondent 5); the decisions the SSC made could not be overturned by the SOCOG Board and SSC “decisions were made for sport and not the bloody SOCOG Board” (respondent 9). Respondent 13, for instance, observed: "what it did do, it gave us a focal point, to give us what was truthful when we were dealing with the NSW Government, because it was so political [the Games]. Now if we hadn't had the SSC then we would have never had [sic] got the truth."

The interview participants noted that the perceived value of the SSC, through the organizational authority it maintained within SOCOG, was based on the premise that the decisions it made were independent of the SOCOG Board and could not be overturned by the Board. As the power of the AOC was embedded in legislation passed by the NSW Parliament, the SSC was not regarded as another committee. "The difference with the Sydney model was that it [the SSC] was actually enshrined in legislation and it had quite significant powers" (respondent 5).

The creation and implementation of the SSC meant there was a reduced requirement for the senior managers within the sport department to rely only on their skills of persuasion and informal networks to get favorable decisions from the SOCOG Board. The extent of the power relations maintained by the AOC power, through the SSC, in the organization of the Sydney Games is described by respondent 31:

[The SSC] was absolutely paramount in ensuring the athletes got number one priority, in the whole bloody thing [they] did a very good job of that to the extent that a big issue like buses going to [athlete] training, where [the NSW Government] were trying to save money, were saying we will send the bus with the team, once it has dropped the team at training it will disappear and we will send another one back to pick it up. [The SSC] said "get f . . . ed," the bus will go with the team and it will stay with the team, right. So they [the SSC] won all those sort of battles, which were about service levels, and it played a very good role and it was a really good way of dealing with the IOC, the international sports federations, and the NOCs.

\section{Management Control}

For the SOCOG Board, an unforeseen outcome and benefit of the establishment of the SSC was that it no longer had authority for the sport department. A crucial point made by the respondents interviewed for this study was that the SSC, with its authority and therefore its capacity to make quick decisions, was very effective given the complex nature of Olympic project planning and management. For instance, a respondent suggested the SSC had a:

\footnotetext{
Major impact - it had the authority of the organizing committee, so if sports had things that they wanted to get done, as long as the SSC was happy with it, you were going to get it done, so I thought that was fairly critical-it was cutting back on the pathway you needed to go through to get things done, decisions made. (respondent 12)
} 
Likewise, respondent 29 stated that the SSC:

Had decision-making authority over everything that impacted athletes, from sports equipment procurement to the quality of amenities in the village. Their role was particularly important in championing the needs of athletes. An example is the procurement of sports equipment. The agenda of the [SOCOG] procurement program was to accept the lowest bid for any tender, regardless of technical quality. Whereas, through the sports equipment working group of the SSC, we were able to ensure that technical quality was the priority driver of tendering decisions.

\section{Planning Cycle}

Respondent 16 noted that the sport department within an OCOG is often disadvantaged because of the timing of its growth within the broader Olympic planning cycle. For instance, large project planning departments such as venue development and construction are very resource dependent and start early in the Olympic planning cycle. This often means that these departments have access to resources and can create a firm power base early in the Olympic planning process. In contrast, sport-specific planning grows in scope and staffing considerably later in the organizational life cycle and intensifies as the start of the competition nears. This point was supported by an analysis of milestone planning reports that were developed by the sport department between 1998 and 2000. These reports showed that when compared to other departments, sport was very dependent on the paid and volunteer staff quite late in the Olympic planning cycle. As suggested by respondent 16 :

If [sport] is not taken into consideration and given the importance that it does have, because it is a sporting event, and have the people in a position of authority, power early on, I think sport would be, it would be tougher for the people within the sport department to deliver it at the end because of the nature of the timing of it. You see some departments are very big and very operative. Whereas sport tends to work with a small staff and build and you have a lot more staff numbers at the time of the Games, whereas other departments don't necessarily do that, that is why it is so important to have it there [the SSC].

Due to the Olympic planning context, the authority of the SSC became increasingly important. As outlined by respondent 16 , without the SSC it would have been much more difficult and "tougher for the people within the sport [department] to deliver it." Furthermore, it was stated that without the authority of the SSC, the sport department would have been a "pretty low priority" for SOCOG (respondent 7). Although respondent 14 argued that the SSC "took control of decision making, the turnaround on decision making was immediate or as near immediate as it could be.” The formal power relations of the SSC therefore assisted the AOC in getting the required cooperation from a range of Olympic stakeholders. "I strongly believe without that high level of representation and the firepower that the SSC had, sport would have had a lesser profile within SOCOG than it did have. The very strong presence of the SSC and the AOC were vital in ensuring there was a strong focus on sport” (respondent 7).

\section{Unforeseen and Unintended Consequences}

Other factors were mentioned by the respondents that supported the view that the creation of the SSC enabled SOCOG to deal with a range of critical issues that developed outside of the sport department. Respondent 15, for instance, suggested that the SSC was especially important when considering the pressure SOCOG faced from unforeseen events. One example given was the Asian financial crisis that took place in 1997 and 1998 (respondent 15). This crisis was an unplanned event that was certainly beyond the control of the SOCOG Board, but had a significant impact on SOCOG's ability to generate commercial income (respondent 31). In 1998, the SOCOG Board sharply revised downwards its sponsorship revenue forecasts principally because of this financial crisis (Toohey, 2001). This point is supported by the Official Report for the XXVII Olympiad, which stated that in 1998 and 1999 SOCOG's financial position diminished: "proposed expenditure was increasing and revenue projections were not being achieved, partly because of factors such as the Asian economic crisis” (Toohey, 2001, p. 31).

\section{Power, Knowledge, and Leadership}

It was also noted that OCOGs that have an experienced sport department benefit from the knowledge that they can provide to other parts of the organization (respondent 25). In this way, organizational 
knowledge shared by the sport department assists other functional areas in dealing with complex sportspecific and sport-related planning and management issues. Importantly, it was noted that the sport department should generate sustainable expectations, and its organizational power should not be used to capture resources that are wasteful and unnecessary. "The sport [department] leadership must manage their own clients'-international federations, competition managers - expectations and ensure that the requirements for the Games are in line with actual needs and not wish lists that waste planning time" (respondent 25). This respondent, when interviewed in 2009, stated that he had been "involved in every [Olympic] Games since Atlanta” and from this experience had learned that:

OCOGs must have strong but balanced leadership as it relates to sport and the Games. When it isn't strong the rest of the organization actually suffers from the lack of good information on what is needed for the Games, i.e., sports, to be successful. All of the other departments in the OCOG need good information and requirements from the sport to succeed in their planning. Being the "athletes' Games," the SSC had a strong hand in ensuring that theme remained a priority in the decision-making process. If a strong body like the SSC didn't exist, one would question where the priorities of sport would fall within the OCOG. (respondent 25)

The legitimized decision-making authority of the SSC within SOCOG, therefore, provided the AOC with the capacity to achieve its central organizational objectives as they related to the Sydney 2000 Olympic Games. Even with its authority within SOCOG, the AOC was still reliant on other Olympic stakeholders in order for it to achieve the planned vision. The next section discusses these findings in the context of the adopted theoretical framework.

\section{Discussion}

The AOC's authority within SOCOG, as expressed through the establishment of the SSC, had significant consequences for the organization of sport at the Sydney Olympics. The SSC maintained authority and institutional legitimacy for the organization of the sport department with the power to make sportspecific and sport-related decisions within SOCOG. In attempting to understand the authority of the SSC within SOCOG, an examination of the AOC's organizational power is required. Clegg (1989) offers a useful template for examining and explaining organizational power relations. His model argues that organizational power flows through three interdependent but overlapping circuits. The circuit analogy is used to reinforce the relational and dynamic nature of power in organizations. The three circuits are called episodic, dispositional, and facilitative circuits of power. According to Bathelt and Taylor (2002), the episodic circuit examines "power as agency;" the dispositional circuit examines "power as relationships;" and the facilitative circuit examines “power as discipline” (p. 95).

\section{Power as Agency}

The episodic circuit concentrates on the causal characteristics that shape organizational power relations. In this first stage, the standing conditions that shape and influence power relations need to be understood (Clegg et al., 2006). A range of power characteristics need to be considered in this circuit. For instance, discovering who controls organizational resources and the nature of those resources: Are they human, financial, technological, or informational resources? In this stage, positional power and therefore organizational authority also need to be considered (Bathelt \& Taylor, 2002). Using this perspective, Marriott (2008) has stated that formal authority in organizations is shaped by the contest for control of organizational resources: "control over resources is another form of power, as is control over knowledge and information” (p. 69). Furthermore, "organizational structures, rules, regulations and procedures, viewed as rational instruments, are seen as reflections of a struggle for political [and organizational] control” (p. 70). Formal authority is therefore shaped by the interdependence of both human agency and historically constituted social structures as they develop and change over time (Stacey, 2003).

The establishment of the SSC was a direct outcome of the resolution of a dispute between the AOC and the NSW Government. The SSC was not a committee with little formal power or authority, rather it was an Olympic agency with distinct decisionmaking power within SOCOG. The formation of the SSC was dependent on the agency of the AOC; 
however, it was not the AOC's agency alone that created the SSC. The authority of the AOC within SOCOG and the establishment and operation of the SCC were interdependent on both social and organizational structures and human agency. The formal authority of the AOC was institutionally interdependent, firstly on the governance of the IOC (as the event owner of the Olympic Games) and secondly on the NSW legal and political structures. These governance structures formed the foundation of the AOC's organizational power within SOCOG.

\section{Power as Relationships}

Dispositional power is the second circuit of power outlined by Clegg (1989). Dispositional power refers to the rules that govern organizations and their membership. This circuit of power works through the creation of rules and regulations that are required to be followed if one is to remain a member of an organization or institution. In this stage, the power of status and the membership that they afford shape and influence power relations (Bathelt \& Taylor, 2002). For example, as a bidding NOC for the 2000 Olympics, the AOC accepted the rules and regulations established by the IOC through its Olympic Charter. Likewise, the NSW Government as the other central party to the bid not only had to agree to the rules and regulations established by the IOC but also committed to the rules and regulations presented by the IOC's representative in Australia, the AOC. This power was particularly expressed through the Endorsement Contract between the AOC and the NSW Government signed in 1991 (Gordon, 1994, 2003). Dispositional power is therefore focused upon social and organizational structures such as rules, regulations, and legislation. These social structures though are never entirely fixed; rather, they are relational and dynamic, changing when people and/or groups of people agree for them to be changed or modified (Stacey, 2007).

\section{Power as Discipline}

Facilitative power is the third circuit. In this circuit, the positive and strategic aspects of power relations are sketched. Here collective effort combines to produce positive organizational outcomes (Clegg et al., 2006). Clegg (1989) draws on the work of Foucault
(1981, 1984), suggesting that organizational power relations are influenced through strategy development and technical innovation. Organizational power relations in this stage can be viewed as more than "power as relationships," as outlined in the second circuit of power (Bathelt \& Taylor, 2002). Rather, this circuit addresses an organization's ability to exploit resources in new and novel ways in order to obtain a competitive advantage. In this stage "standing conditions no longer stand. Rule fixing, meaning, and memberships are changed, potent uncertainty and dynamism [are introduced] into power relations" (Clegg, 1989, p. 236).

With the formation of the SSC, the SOCOG Board no longer maintained responsibility or authority for the sport department. A central (and unintended) consequence of the decision to transfer authority for sport to the SSC was that the SOCOG Board no longer needed to devote time to making decisions regarding a crucial part of the Sydney Games. Instead the SOCOG Board focused on other strategic and organizational matters that consume a lot of time and energy, such as the generation of income and the containment of costs. Due to this transfer in decision-making power, the SSC provided the sport department with the autonomy to make 540 decisions between 1996 and 2001 (Frawley, 2010).

As has been alluded to earlier in this discussion, the power relations that can be exerted by a strong organizational department or subunit are interdependent on the available resources at a certain point in time (Dopson, 1997). This point was reinforced by a respondent who suggested that the sport department within an OCOG is often disadvantaged because of its place within the Olympic planning cycle (respondent 16). In contrast to some large Olympic planning areas (such as venue management and marketing), sport-related planning grows in scope and staffing later in the event planning process and intensifies as the competition nears. The authority of the SSC, in this organizational context, reflected a rationalization that the sport department benefited from the AOC maintaining considerable power within SOCOG.

According to Clegg et al. (2006), "all forms of organization are forms of organization of social relations. All social relations involve power relations. Power is evident in relations not only of ownership and control but also of structuration and design" 
(p. 89). On one hand the establishment of the SSC reflected the level of authority and control the AOC maintained within SOCOG, but on the other hand it also highlighted the interdependent relationship it had with the NSW Government. The AOC, as the host NOC, not only maintained institutional power, as formulated by the Olympic Charter, but it also began with and maintained substantial Olympic knowledge and expertise. The formation of the SSC allowed the AOC to use and maximize its knowledge and experience within SOCOG. Knowledge and experience can play a "key role in extending, limiting, and otherwise shaping" organizational resources and property rights (Clegg, 2003, p. 536). Through the formation of the SSC, the AOC shaped its own Olympic future as well as the future experiences of its constituents, the Olympic athletes the AOC stated it was there to serve and be "governed" by. As outlined by Dahl (1961), power researchers need to develop an understanding of organizations by asking the question: "Who governs?" Moreover, Putnam (1976) has commented that insofar as organizational decisions matter, so too do organizational decision makers. Having people with power who knew the Olympic movement and who made decisions in the best interests of the athletes was regarded as a critical feature of the SSC and the Sydney Olympics by those who worked in and managed the sport department.

The AOC's institutional power within SOCOG, and especially its ability through the SSC to make sport-specific and sport-related decisions, was central to maintaining its Olympic authority in the organization of the Sydney Games. The members of the SSC had the capacity to make sport-specific and sport-related decisions, which was viewed as important, in that without the SSC members of the SOCOG Board would not only have had the power to make sport decisions, but also the power to defer or not to make decisions at all. As outlined by Lukes (1974), power relations in organizations are not only influenced by decisions that are made by a board, but also by "decisions” that are not made.

\section{Future Research}

As this study examined a single case, the Sydney 2000 Olympic Games, the findings that emerged are highly contextual. In order to build a more thorough understanding of mega-event organization, future research needs to be undertaken across multiple Olympic Games. Additional research should be considered that investigates Games that have already been staged. Such an approach could provide the opportunity for longitudinal analysis and a comparison of how various internal and external stakeholders shape Olympic organization and implementation. In addition to the analysis of the role of host NOCs and host governments in Games organization other key stakeholders (i.e., the international sport federations, sponsors, host broadcasters, and international media) should be explored.

Through the analysis of multiple Olympic Games, the findings from this study can be further developed, extended, and refined. Such research could explore how Olympic stakeholders, such as host NOCs, design their organizational priorities and strategies when they are involved in the management of an Olympics. A longitudinal approach to researching Olympic organization, therefore, would add a great deal to the existing mega-event body of knowledge. This longer term research perspective also fits well with the approach outlined by Eliasian organizational theorists. Researchers such as Newton $(2001,2004)$ and Dopson $(2001,2005)$, for instance, recommend that management researchers should spend more time considering the broader historical context when analyzing organizational development and change. They argue that such an approach provides management researchers with a fuller understanding of the organizational interdependencies that shape stakeholder involvement and performance. Ultimately, this means that host NOCs as a vital stakeholder of the Olympic Games can achieve a deeper understanding of how they can best position themselves in order to achieve their organization's objectives.

A second area worth exploring through future research is the role played by host NOCs in other parts of an OCOG outside the sport department. There is scope for researchers to explore, for instance, the role of the AOC in the planning and organization of the Olympic village at the Sydney Games. The AOC, through the SSC, not only managed the SOCOG sport department but also played a prominent role in Olympic village 
planning. Further research is required to understand the full impact the AOC had in this area of Olympic planning. Research into how host NOCs work with OCOG marketing departments to leverage their Olympic Games association is also worth detailed investigation. For example, to date, little research has explored how previous host NOCs have attempted to exploit the potential marketing advantage gained from the hosting of an Olympics (Morgan \& Frawley, 2011).

A third vital area that should be considered for future research is the area of knowledge transfer. Mega-event and Olympic Games researchers should focus on how host NOCs transfer the knowledge they gain from their Olympic involvement to future host NOCs. Every time an Olympic Games is staged, whether Summer or Winter Games, a host NOC is involved in the process as a key stakeholder. To date, however, little research has been conducted that has examined the effectiveness of this knowledge transfer. Although researchers such as Halbwirth and Toohey (2001) have examined knowledge management processes and how these processes can assist an OCOG as it grows, no studies have explored the place of the host NOC in these or similar processes. Future research, therefore, should investigate how host NOCs pass on information from one another and what impact this knowledge sharing has on Olympic management processes. By undertaking research such as this a greater understanding of Olympic organization will be achieved and the improvements can be developed and implemented for the management of future Games.

\section{Conclusion}

In conclusion, the establishment of the SSC enabled SOCOG to deal more effectively with the complexity of the Games organization, specifically its management of sport. The SSC took away from the Board its authority for the sport department. As a result, the legitimacy of the SSC, within SOCOG, provided the AOC with a forum and the resource capability to achieve its stated vision of organizing an Olympic Games for the athletes. The AOC's authority within SOCOG, after the creation of the SSC, therefore, provided the sport department with a high degree of organizational autonomy.

\section{References}

Arnason, J. (1987). Figurational sociology as a counterparadigm. Theory, Culture and Society, 4, 429-456.

Bathelt, H., \& Taylor, M. (2002). Clusters, power and place: Inequality and local growth in time-space. Geografiska Annaler, 84, 93-109.

Bramwell, B. (1997). Strategic planning before and after a mega-event. Tourism Management, 18, 167-176.

Bryman, A. (2004). Social research methods. Oxford: Oxford University Press.

Cashman, R. (2006). The bitter-sweet awakening: The legacy of the Sydney 2000 Olympic Games. Sydney: Walla Walla Press.

Clegg, S. (1989). Frameworks of power. London: Sage.

Clegg, S. (2003). Managing organizations futures in a changing world of power/knowledge. In H. Tsoukas \& C. Knudsen (Eds.), Handbook of organization theory. New York: Oxford University Press.

Clegg, S., Courpasson, D., \& Phillips, N. (2006). Power and organizations. London: Sage.

Clegg, S., \& Hardy, C. (1996). Conclusion: Representations. In S. R. Clegg, C. Hardy, \& W. R. Nord (Eds.), Handbook of organizations studies. London: Sage.

Dahl, R. A. (1961). Who governs? Democracy and power in an American city. New Haven, CT: Yale University Press.

Dobson, N., \& Sinnamon, R. (2001). A critical analysis of the organization of major sports events. In C. Gratton \& I. Henry (Eds.), Sport in the city. London: Routledge.

Dopson, S. (1997). Managing ambiguity and change: The case of the NHS. Houndmills, Hampshire, UK: Macmillan Press.

Dopson, S. (2001). Applying an Eliasian approach to organizational analysis. Organization, 8, 515-535.

Dopson, S. (2005). The diffusion of medical innovations: Can figurational sociology contribute? Organization Studies, 26, 1125-1144.

Elias, N. (1994). The civilizing process: The history of manners and state formation and civilization. Oxford: Blackwell.

Flyvbjerg, B. (1998). Rationality and power: Democracy in practice. London: University of Chicago Press.

Flyvbjerg, B. (2001). Making social science matter: Why social inquiry fails and how it can succeed again. Cambridge: Cambridge University Press.

Flyvbjerg, B. (2004). Phronetic planning research: Theoretical and methodological reflections. Planning Theory and Practice, 5, 283-306.

Flyvbjerg, B. (2006). Five misunderstandings about casestudy research. Qualitative Inquiry, 12, 219-245.

Foucault, M. (1977). Discipline and punishment: Birth of the prison. Harmondsworth, UK: Penguin.

Foucault, M. (1981). Power/knowledge: Selected interviews and other writings 1972-1977. Brighton, UK: Haverster Press.

Foucault, M. (1984). Polemics, politics and problematization. In M. Foucault \& P. Rainbow (Eds.), The Foucault reader. New York: Pantheon Books. 
Frawley, S. (2010). Organizing sport at the Olympic Games: The case of Sydney 2000. Unpublished Ph.D. dissertation, Griffith University, Brisbane.

Frawley, S. (2013). Organising sport at the Olympic Games: The case of Sydney 2000. International Journal of the History of Sport, 5, 527-544.

Frawley, S., \& Cush, A. (2011). Major sport events and participation legacy. Managing Leisure, 16, 65-76.

Frawley, S., \& Toohey, K. (2009). The importance of prior knowledge: The Australian Olympic Committee and the Sydney 2000 Olympic Games. Sport in Society, 7, 947-966.

Getz, D. (1993). Corporate culture in not-for-profit festival organizations: Concepts and potential applications. Festival Management \& Event Tourism, 1, 11-17.

Gordon, H. (2003). The time of our lives: Inside the Sydney Olympics. St. Lucia, Australia: Queensland University Press.

Gordon, H. (1994). Australia and the Olympic Games. St. Lucia, Australia: Queensland University Press.

Gratton, C., \& Jones, I. (2004). Research methods for sport studies. London: Routledge.

Halbwirth, S., \& Toohey, K. (2001). The Olympic Games and knowledge management: A case study of the Sydney Organizing Committee of the Olympic Games. European Sport Management Quarterly, 1, 91-111.

Hall, C. M. (1992). Hallmark tourist events: Impacts, management and planning. London: Belhaven Press.

Hill, C. R. (1992). Olympic politics. Manchester, UK: Manchester University Press.

Hill, C. R. (1996). Olympic politics (2nd ed.). Manchester, UK: Manchester University Press.

Lesjo, J. H. (2000). Lillehammer 1994: Planning, figurations and the "Green" Winter Games. International Review for the Sociology of Sport, 35, 282-293.

Lowendahl, B. (1995). Organizing the Lillehammer Olympic Winter Games. Scandinavian Journal of Management, 11, 347-362.

Lukes, S. (1974). Power a radical view. London: Macmillan.

Malfas, M. (2003). An organizational analysis of the organizing committees for the Olympic Games. Unpublished Doctor of Philosophy, Loughborough University, Loughborough.

Marriott, S. (2008). Inclusion and exclusion at the NHS. Unpublished Doctor of Management, University of Hertfordshire, Hertfordshire.

McDonald, P. (1991). The Los Angeles Olympic Organizing Committee: Developing organizational culture in the short run. In P. Frost, L. Moore, M. Louis, C. Lundberg, \& J. Martin (Eds.), Reframing organizational culture. Newbury Park, CA: Sage.

Miles, M. B., \& Huberman, A. M. (1994). Qualitative data analysis: An expanded sourcebook (2nd ed.). Thousand Oaks, CA: Sage Publications.

Minis, I., \& Tsamboulas, D. (2008). Contingency planning and war gaming for the transport operations of the Athens 2004 Olympic Games. Transport Reviews, 28, 259-280.
Mintzberg, H. (1979). The structuring of organizations. Englewood Cliffs, NJ: Prentice Hall.

Morgan, A., \& Frawley, S. (2011). Sponsorship legacy and the hosting of an Olympic Games. Journal of Sponsorship, 4, 220-235.

Murphy, P., Sheard, K., \& Waddington, I. (2002). Figurational sociology. In E. Dunning \& J. Coakley (Eds.), The handbook of sport studies. London: Sage.

Newton, T. (1999). Power, subjectivity and British industrial and organizational sociology: The relevance of the work of Norbert Elias. Sociology, 33, 411-440.

Newton, T. (2001). Organization: The relevance and the limitations of Elias. Organization, 8, 467-495.

Newton, T. (2004). From freemasons to the employee: Organization, history and subjectivity. Organization Studies, 25, 1363-1387.

Newton, T., \& Smith, D. (2002). Introduction: Norbert Elias and the civilized organization. In A. Van Iterson, W. Mastenbroek, T. Newton, \& D. Smith (Eds.), The civilized organization. Amsterdam: John Benjamins.

Parent, M. (2005). Large-scale sporting events: Organizing committees and stakeholders. Unpublished Ph.D. thesis, University of Alberta, Edmonton, Alberta.

Parent, M. (2008). Evolution and issue patterns for majorsport-event organizing committees and their stakeholders. Journal of Sport Management, 22, 135-164.

Parent, M., \& Deephouse, D. (2007). A case study of stakeholder identification and prioritization by managers. Journal of Business Ethics, 75, 1-23.

Parent, M., \& Seguin, B. (2007). Factors that led to the drowning of a world championship organizing committee: A stakeholder approach. European Sport Management Quarterly, 7, 187-212.

Payne, M. (2006). Olympic turnaround: How the Olympic Games stepped back from the brink of extinction to become the world's best known brand. Westport, CT: Praeger Publishers.

Preuss, H. (2000). Economics of the Olympic Games: Hosting the games 1972-2000. Sydney: Walla Walla Press.

Putnam, R. D. (1976). The comparative study of political elites. Englewood Cliffs, NJ: Prentice-Hall.

Sydney Organizing Committee for the Olympic Games. (2000). SOCOG sport program operational plan. Sydney: Author.

Stacey, R. (2003). Learning as an activity of interdependent people. The Learning Organization, 10, 325-331.

Stacey, R. (2007). The challenge of human interdependence: Consequences for thinking about the day to day practice of management in organizations. European Business Review, 19, 292-302.

Stamatakis, H., Gargalianos, D., Afthinos, Y., \& Nassis, P. (2003). Venue contingency planning for the Sydney 2000 Olympic Games. Facilities, 21, 115-125.

Theodoraki, E. (2007). Olympic event organization. Oxford: Elsevier.

Toohey, K. (2001). The official report of the games of the XXVII Olympiad. Sydney: SOCOG. 
Toohey, K., \& Taylor, T. (2008). Mega-events, fear and risk: Terrorism at the Olympic Games. Journal of Sport Management, 22, 451-469.

Van Iterson, A., Mastenbroek, W., Newton, T., \& Smith, D. (2002). The civilized organization: Norbert Elias and the future of organization studies. Amsterdam: John Benjamins.
Van Krieken, R. (1998). Norbert Elias. New York: Routledge. Veal, A. J. (2006). Research methods for leisure and tourism: A practical guide (2nd ed.). Sydney: Prentice Hall. Weick, K. (1969). The social psychology of organizing. Reading, MA: Addison-Wesley Publishing Company. 